\title{
Study of Adverse Drug Reactions Associated with Chemotherapy of Breast Cancer
}

\author{
Barli Anvisha ${ }^{1}$, Bonthu Sai Sireesha ${ }^{2 *}$, Chilla Anitha ${ }^{3}$, \\ Sarvana Sravya ${ }^{4}$, Dr. Shubham Babu Gupta ${ }^{5}$, B Rama ${ }^{6}$, Raj Kamal ${ }^{7}$ \\ Department of Pharmacy Practice, Pharmaceutical Sciences, \\ Malla Reddy Institute of Pharmaceutical Science, \\ Kompally, Secunderabad-500100, Telanagana, India
}

Abstract:-

\section{$>$ Introduction/ Background}

Breast carcinoma is an important malignant tumor which occurs as non-invasive and invasive cancer with its various morphologic varieties. One of the treatments used for breast cancer is chemotherapy which has many side-effects.

\section{$>$ Aim and Objectives}

The aim of the present study is to assess the adverse drug reactions associated with chemotherapy of breast cancer.

\section{$>$ Methodology}

The study is observational, prospective study that includes all female patients admitted in day-care ward for chemotherapy cycles.

\section{Result}

The percentage of common side-effects were Nausea (75\%), Alopecia (72\%), Emesis (69\%), Diarrhoea and Insomnia (64\%), Asthenia (50\%), Black nails $(32 \%)$. There was a gradual reduction in weight of the study population.

\section{Conclusion}

The study emphasized the need to focus on management of other side-effects, for close monitoring over side-effects, muscle strength, weight changes, psychological health of the patient.
Keywords:- Breast Carcinoma, Chemotherapy, Side Effects, Adverse Effects, Management of Side Effects.

\section{INTRODUCTION}

Breast cancer incidence rate varies in different countries but is particularly high in developed countries. Breast cancer has ranked number one cancer among Indian females with an age-adjusted rate as high as 25.8 per 100,000 women and mortality 12.7 per 100,000 women. The incidence is higher in peri-menopausal women and uncommon before the age of 25 years

Breast cancer is a disease in which certain cells in the breast become abnormal and multiply uncontrollably to form a tumor. In both women and men, the most common form of breast cancer begins in cells lining the milk ducts (ductal cancer). In women, cancer can also develop in the glands that produce milk (lobular cancer). Most men have little or no lobular tissue, so lobular cancer in men is very rare.

In some cases, cancerous tumors can invade surrounding tissue and spread to other parts of the body. If breast cancer spreads, cancerous cells most often appear in the bones, liver, lungs, or brain.

The various forms of breast cancer are divided into three major groups; they are Invasive Breast carcinomas, Non-invasive breast carcinomas and Paget's disease of Nipple. 
ISSN No:-2456-2165

\begin{tabular}{|c|c|c|c|}
\hline \multicolumn{4}{|c|}{ Table 1:- chemotherapy guidelines of Breast cancer by WHO } \\
\hline Regimen & Drugs & Standards & Cycles \\
\hline $\mathbf{A C}$ & Doxorubicin Cyclophosphamide & $600 \mathrm{mg} / \mathrm{m}^{2} \mathrm{IV}$, day $1600 \mathrm{mg} / \mathrm{m}^{2} \mathrm{IV}$, day 1 & $\begin{array}{l}\text { Repeat every } 21 \text { days for } \\
4 \text { cycles }\end{array}$ \\
\hline FAC & $\begin{array}{l}\text { Fluorouracil Doxorubicin } \\
\text { Cyclophosphamide }\end{array}$ & $\begin{array}{c}500 \mathrm{mg} / \mathrm{m}^{2} \mathrm{IV}, 1-4 \text { days } 50 \mathrm{mg} / \mathrm{m}^{2} \mathrm{IV} \text {, } \\
\text { infusion over } 72 \text { hours } 500 \mathrm{mg} / \mathrm{m}^{2} \mathrm{IV} \text {, day } \\
1\end{array}$ & $\begin{array}{l}\text { Repeat every } 21 \text { days for } \\
6 \text { cycles }\end{array}$ \\
\hline $\begin{array}{c}\text { AC+ } \\
\text { Taxol }\end{array}$ & $\begin{array}{l}\text { Doxorubicin Cyclophosphamide } \\
\text { Followed by Paclitaxel }\end{array}$ & $\begin{array}{c}60 \mathrm{mg} / \mathrm{m}^{2} \mathrm{IV} \text {, day } 1600 \mathrm{mg} / \mathrm{m}^{2} \mathrm{IV}, \text { day } 1 \\
80 \mathrm{mg} / \mathrm{m}^{2} \mathrm{IV} \text { weekly }\end{array}$ & $\begin{array}{l}\text { Repeat every } 21 \text { days for } \\
4 \text { cycles } \\
\text { Every } 7 \text { days for } 21 \text { cycles }\end{array}$ \\
\hline FEC & $\begin{array}{l}\text { Fluorouracil Epirubicin } \\
\text { Cyclophosphamide }\end{array}$ & $\begin{array}{c}500 \mathrm{mg} / \mathrm{m}^{2} \mathrm{IV} \text {, day } 1100 \mathrm{mg} / \mathrm{m}^{2} \mathrm{IV} \text { bolus. } \\
500 \mathrm{mg} / \mathrm{m}^{2} \mathrm{IV} \text {, day } 1\end{array}$ & $\begin{array}{c}\text { Repeat every } 21 \text { days for } \\
6 \text { cycles }\end{array}$ \\
\hline CMF & $\begin{array}{l}\text { Cyclophosphamide } \\
\text { Methotrexate Fluorouracil }\end{array}$ & $\begin{array}{c}100 \mathrm{mg} / \mathrm{m}^{2} \mathrm{PO}, \text { OD for } 1-14 \text { days } \\
40 \mathrm{mg} / \mathrm{m}^{2} \mathrm{IV}, 1-8 \text { days } 600 \mathrm{mg} / \mathrm{m}^{2} \mathrm{IV}, 1-8 \\
\text { days }\end{array}$ & $\begin{array}{c}\text { Repeat for } 28 \text { days for } 6 \\
\text { cycles }\end{array}$ \\
\hline TC & Docetaxel Cyclophosphamide & $75 \mathrm{mg} / \mathrm{m}^{2} \mathrm{IV}$, day $1600 \mathrm{mg} / \mathrm{m}^{2} \mathrm{IV}$, day 1 & $\begin{array}{l}\text { Repeat every } 21 \text { days for } \\
4 \text { cycles }\end{array}$ \\
\hline TAC & $\begin{array}{l}\text { Docetaxel Doxorubicin } \\
\text { Cyclophosphamide }\end{array}$ & $\begin{array}{c}75 \mathrm{mg} / \mathrm{m}^{2} \mathrm{IV}, 1-4 \text { days } 50 \mathrm{mg} / \mathrm{m}^{2} \mathrm{IV} \text { bolus, } \\
\text { day } 1500 \mathrm{mg} / \mathrm{m}^{2} \mathrm{IV} \text {, day } 1\end{array}$ & $\begin{array}{l}\text { Repeat every } 21 \text { days for } \\
6 \text { cycles (+growth factor } \\
\text { support) }\end{array}$ \\
\hline Taxol+ FAC & $\begin{array}{c}\text { Paclitaxel Followed by Fluorouracil } \\
\text { Doxorubicin } \\
\text { Cyclophosphamide }\end{array}$ & $\begin{array}{c}80 \mathrm{mg} / \mathrm{m}^{2} / \text { week, IV }-1 \mathrm{hr} \text {. } \\
500 \mathrm{mg} / \mathrm{m}^{2} \mathrm{IV}, 1-4 \text { days } 50 \mathrm{mg} / \mathrm{m}^{2} \mathrm{IV} \\
\text { infusion over } 72 \text { hours } 500 \mathrm{mg} / \mathrm{m}^{2} \mathrm{IV} \text {, day } \\
1\end{array}$ & $\begin{array}{l}\text { Every week for } 12 \text { weeks } \\
\text { Repeat every } 21- \\
28 \text { days for } 4 \text { cycles }\end{array}$ \\
\hline CEF & $\begin{array}{c}\text { Cyclophosphamide Epirubicin } \\
\text { Fluorouracil }\end{array}$ & $\begin{array}{c}75 \mathrm{mg} / \mathrm{m}^{2} \mathrm{PO} / \mathrm{OD}, 1-14 \\
60 \mathrm{mg} / \mathrm{m}^{2} \mathrm{IV}, \text { days } 1-8600 \mathrm{mg} / \mathrm{m}^{2} \mathrm{IV}, \\
\text { days } 1-8\end{array}$ & $\begin{array}{l}\text { Repeat every } 21 \text { days for } \\
6 \text { cycles }\end{array}$ \\
\hline $\begin{array}{l}\text { Dose- dense } \mathrm{AC}+ \\
\text { Taxol }\end{array}$ & $\begin{array}{c}\text { Doxorubicin Cyclophosphamide } \\
\text { Followed by Paclitaxel }\end{array}$ & $\begin{array}{c}60 \mathrm{mg} / \mathrm{m}^{2} \mathrm{IV} \text { bolus, day } 1600 \mathrm{mg} / \mathrm{m}^{2} \mathrm{IV} \\
\text { day } 1 \\
175 \mathrm{mg} / \mathrm{m}^{2} \mathrm{IV} \text { over } 3 \mathrm{hrs} .\end{array}$ & $\begin{array}{l}\text { Repeat every } 14 \text { days for } \\
\qquad 4 \text { cycles } \\
\text { Repeat every } 14 \text { days for } \\
4 \text { cycles }\end{array}$ \\
\hline
\end{tabular}

\section{MATERIALS AND METHODS}

All relevant and necessary data for this study was collected from: Patient case notes, Treatment charts, adverse drug effects chart of chemotherapy, laboratory reports, Interviewing patient/ patient care taker, Interviewing Healthcare Professionals. The study period was planned from October 2018 to March 2019. The data collection for this study was done in the following hospitals:

> Basavatarakam Indo-American Hospital of Oncology and Research Institute, Banjara Hills.

Malla Reddy Cancer Hospital, Suraram, Telangana.

$>$ Malla Reddy Narayana Multi-speciality Hospital, Suraram, Telangana.
This is a retro-prospective observational study conducted at Daycare ward of Basavatarakam IndoAmerican Cancer Hospital \& Research Institute and Malla Reddy Narayana Multi-speciality Hospital. Patients were who admitted to the ward (prospective) and who were admitted in the year 2018 (retrospective) were enrolled. The Breast Cancer patients visiting the hospital are evaluated, diagnosed and prescribed with a suitable cycle of chemotherapy and calculated dose based on their Body Surface Area (BSA). Using a suitable design data collection form, the following details were collected: Patient demographics, prescription chart, lab data, data of each cycle, discharge data for each cycle, surgical note (if surgery is done), progress chart, doctor's notes and nursing notes. Different brand drugs were used among the study 
population, so there is a chance that the side-effect is caused by adjuvant rather than active ingredient (anti-neoplastic drug), few patients were other medications for comorbidities, so it was difficult to distinguish the cause of side-effect. Anti-emetics and Cortisone were given prior to chemotherapy, which reduces the severity and risk of adverse drug reactions, and Patients were asked about the side-effects they observed during each of the previous cycles and their voice was noted manually

\section{STUDY CRITERIA}

The study is carried out using the following factors.

$>$ Inclusion criteria:

- Patients on chemotherapy for Breast cancer management.

- Patients on chemotherapy for Breast cancer reoccurrence and management.

\section{$>$ Exclusion criteria:}

- Male patients with Breast cancer.

- Female patients with ovarian cancer.

- Female patients in whom breast cancer is secondary in occurrence.

- Patients undergoing other adjuvant therapies like hormonal therapy, radiation therapy.

\section{* Study Period:}

The study is conducted for a six months period from October 2018 to March 2019.

\section{RESULTS AND DISCUSSION}

The collected data showed the presence of mild to severe side-effects in patients due to chemotherapy along with tumor reduction. In our results, most of the patients showed common side-effects like nausea, alopecia, emesis, diarrhea, insomnia, asthenia, change in nail colour, chills, fever and anorexia during early cycles of chemotherapy. Among this only nausea, vomiting and pain were focused for management during cancer treatment as per guidelines of WHO for these side-effects. The results also showed weightloss in many patients as well as weight gain in a few patients. Maintaining an ideal weight range through-out chemotherapy may help in better recovery, which can be achieved by an individualized diet plan and selection of better nutritional supplement based on the need of a patient. This will also assist in overcoming the major problem of weakness among breast cancer population. The reoccurrence of breast cancer was prevented by opting mastectomy than lumpectomy in the hospital. The reoccurrence in $36 \%$ of patients can be due to other causes; like poor post-operative care, which can be considered to prevent further reoccurrence in them.

Peri-menopause women (women between ages 30-40) were more affected with breast cancer as per data. Increasing breast cancer awareness and knowledge on self-examination among pre-menopause and peri-menopause women will help in early detection of cancer and proper treatment can be initiated on time.

Ward rounds revealed improper adherence to cycle schedules and late admissions for supportive care. The various reasons behind in-adherence were found to be lack of interest in therapy due to its monthly schedule for prolonged time, lack of knowledge on cycle schedules. Medication adherence may be improved by use of PIL reminders, highlighted indication of the date of next cycle or use of AI programmed applications that store the complete data of the specific patient, assist and motivate them through-out the chemotherapy course; self-motivation building sessions for patients might be helpful.

Interaction with the study population presented the eager of knowledge about diet and diet pattern. Presentation of individualized diet counseling by a nutritionist along with information leaflets on diet may help in degrading the anxiousness among affected.

Overall results of this study show that most participants had moderate to adequate knowledge regarding anti-neoplastic use. They were aware of the risks of common side-effects like alopecia, nausea, vomiting, weakness and pain pathologized by chemotherapy of breast cancer. Majority of patients were expressing their anxiousness due to side-effects and inappropriate knowledge regarding effective management of side-effect.

\section{STATISTICAL ANALYSIS}

\section{Study of common side-effects in study population:}

- Figure 1: Showing overall common side-effects reported during conduct of study.

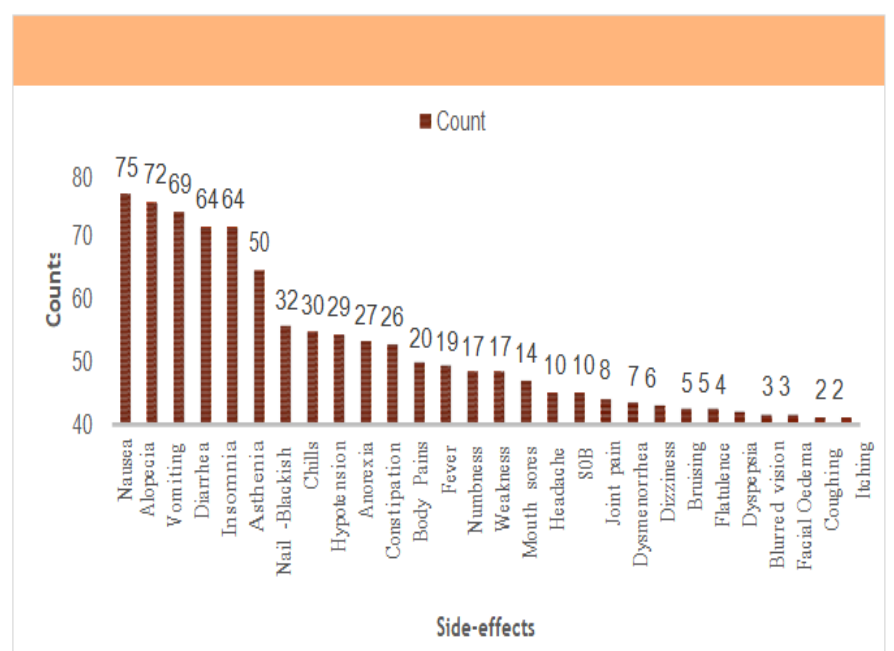

Fig 1:- Common Side-effects

Study of weight changes with chemotherapy cycle in study population:

- Figure 2: Showing the frequency of weight loss and weight gain in thestudy population as a pie chart. 


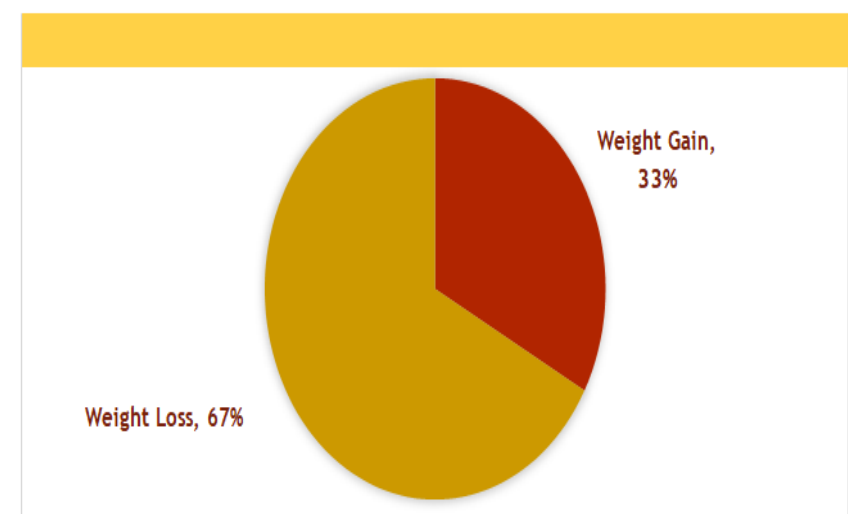

Fig 2:- Frequency of weight loss and weight gain.
Correlation-Regression analysis to know the relation between BMI and stage of breast cancer

- Table 2: Showing regression statistics.

- Table 3: ANOVA analysis and calculation of Fsignificance.

- Table 4: Showing P-value calculation from the above data.

- Figure 3: Showing Co-relation between BMI and Stage of Cancer.

\begin{tabular}{|c|c|}
\hline \multicolumn{2}{|c|}{ Table 2: Regression statistics } \\
\hline Multiple R & 0.100783546 \\
\hline R Square & 0.010157323 \\
\hline Adjusted R Square & $5.68876 \mathrm{E}-05$ \\
\hline Standard Error & 0.868911706 \\
\hline Observations & 100 \\
\hline
\end{tabular}

\begin{tabular}{|c|c|c|c|c|c|}
\hline & \multicolumn{7}{|c|}{ Table 3: ANOVA analysis } \\
\hline & Df & SS & MS & F & Significance F \\
\hline Regression & 1 & 0.759259903 & 0.75926 & 1.005632196 & 0.318421192 \\
\hline Residual & 98 & 73.9907401 & 0.755008 & & \\
\hline Total & 99 & 74.75 & & \\
\hline
\end{tabular}

\begin{tabular}{|c|c|c|}
\hline \multicolumn{2}{|c|}{ Table 4: Calculation of p-value. } \\
\hline & Intercept & Initial BMI \\
\hline Coefficients & $\mathbf{2 . 1 0 0 1 3 7 0 6 8}$ & $\mathbf{0 . 0 1 6 4 5 3 7 8 5}$ \\
\hline Standard error & $\mathbf{0 . 4 5 6 9 3 9 0 4 6}$ & $\mathbf{0 . 0 1 6 4 0 7 6 4 4}$ \\
\hline T stat & $\mathbf{4 . 5 9 6 0 9 9}$ & $\mathbf{1 . 0 0 2 8 1 2}$ \\
\hline P value & $\mathbf{0 . 3 1 8 4 2 1 1 9 2}$ & $\mathbf{1 . 2 8 4 3 E - 0 5}$ \\
\hline Lower 95\% & $\mathbf{1 . 1 9 3 3 5 6 4 0 2}$ & $\mathbf{0 . 0 1 6 1 0 6 6 5 1}$ \\
\hline Upper 95\% & $\mathbf{3 . 0 0 6 9 1 7 7 3 4}$ & $\mathbf{0 . 0 4 9 0 1 4 2 2 1}$ \\
\hline Lower 95.0\% & $\mathbf{1 . 1 9 3 3 5 6 4 0 2}$ & $\mathbf{0 . 0 1 6 1 0 6 6 5 1}$ \\
\hline Upper 95.0\% & $\mathbf{3 . 0 0 6 9 1 7 7 3 4}$ & $\mathbf{0 . 0 4 9 0 1 4 2 2 1}$ \\
\hline
\end{tabular}

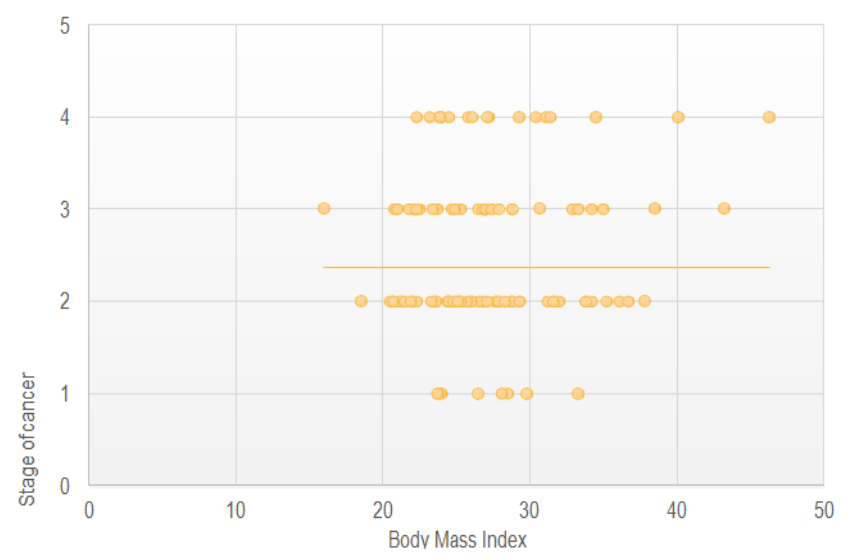

Fig 3:- Corelation between BMI and Stage of Cancer $y=0.0165 x+2.100, R^{2}=0.0102$

Relation between menopause status and stage of cancer:

- Table 5: Showing distribution of study population in premenopause, perimenopause and post-menopause along with the stage of cancer.

- Figure 4: Showing distribution of study population by menopausal status and stage of cancer present. 


\begin{tabular}{|c|c|c|c|c|}
\hline \multicolumn{5}{|c|}{ Table 5: Count of patients based on menopause status } \\
\hline & Stage 1 & Stage 2 & Stage 3 & Stage 4 \\
\hline Pre-menopause & 1 & 0 & 1 & 1 \\
\hline Perimenopause & 5 & 26 & 17 & 11 \\
\hline Post menopause & 2 & 21 & 10 & 5 \\
\hline
\end{tabular}

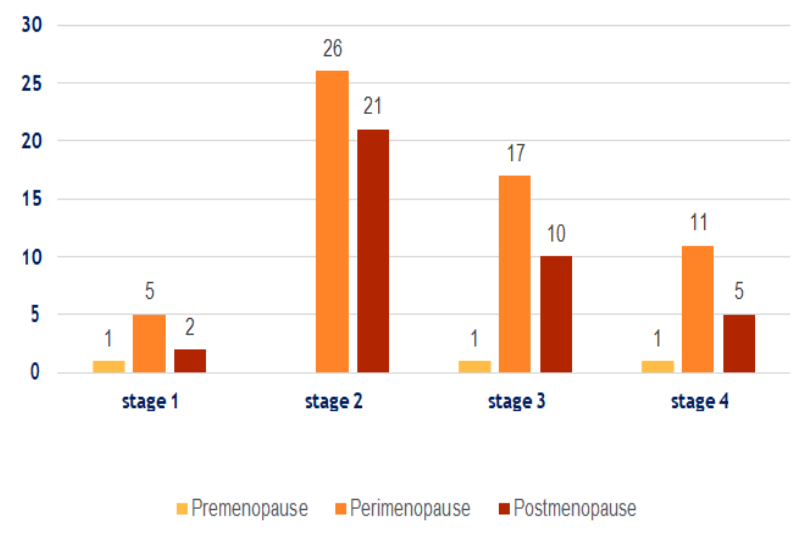

Fig 4:-MenopausestatusandstageofCancer

Distribution of study population based on type of cancer present:

- Table 6: Showing the number of patients having benign breast cancer and malignant breast cancer.

- Figure 5: Representation of distribution of study population based on type of cancer.

Table 6: Count of Benign cancer and malignant cancer.

\section{Number of patients}

Benign breast cancer

Malignant breast cancer

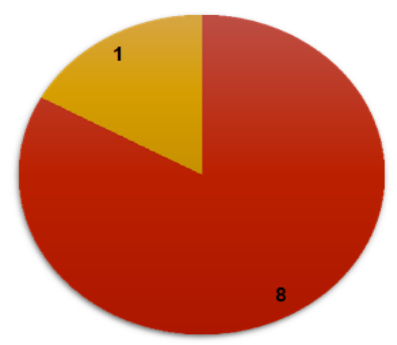

- Benign cancer a Malignant cancer
83

17
Distribution of study population based on hormone status of the cancer:

- Table7: Showing the number of patients having specific hormone receptor status.

- Figure 6: Representation of distribution of study population based on the hormone receptor status.

Table 7: Hormone Status in the study population.

\begin{tabular}{|c||c||c||c|c|}
\hline & Oestrogen & Progesterone & HER2 & Triple negative \\
\hline \hline Positive & 52 & 46 & 36 & 0 \\
\hline \hline Negative & 26 & 32 & 42 & 22 \\
\hline \hline
\end{tabular}

Triple negative

HER2

Progestrone

Oestrogen

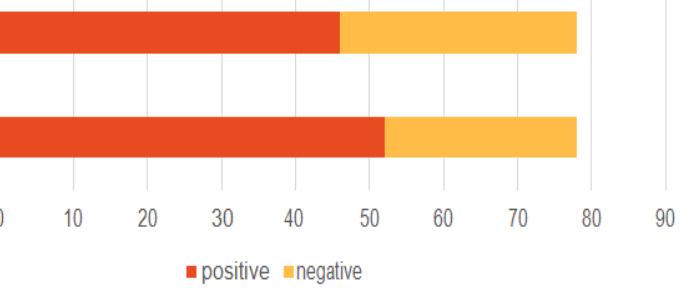

Fig 6:- Hormone Receptor Status in Study population

Reoccurrence of breast cancer in study population:

- Table 8: Representing the number of patients in study population showing reoccurrence of breast cancer or who are admitted with a cause of recurrent breast cancer.

- Figure 7: Representing a pie diagram showing the percentage of patients showing reoccurrence of breast cancer.

Fig 5:- Distribution of population on basis of type of cancer 


\begin{tabular}{|c|c|c|}
\hline Table 8: Number of breast cancer patients showing \\
\hline & \multicolumn{3}{|c|}{ reoccurrence } \\
\hline & Reoccurrence & No reoccurrence \\
\hline $\begin{array}{c}\text { Number of } \\
\text { patients }\end{array}$ & 36 & \\
\hline
\end{tabular}

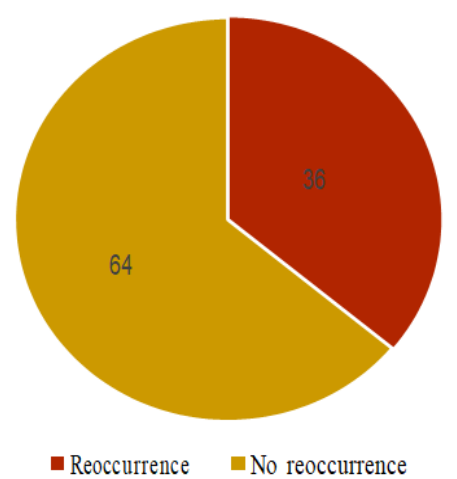

Fig 7:- Percentage of patients with reoccurrence of breast cancer

Genetic history of study population:

- Table 9: Represent the count of patients in the study population having a family history of breast cancer.

- Figure 8: Representing the percentage of patients in the study population having a family history of breast cancer, in the form of bar-diagram.

\begin{tabular}{|c|c|}
\hline Table 9: Patients having a genetic history of breast \\
cancer.
\end{tabular}

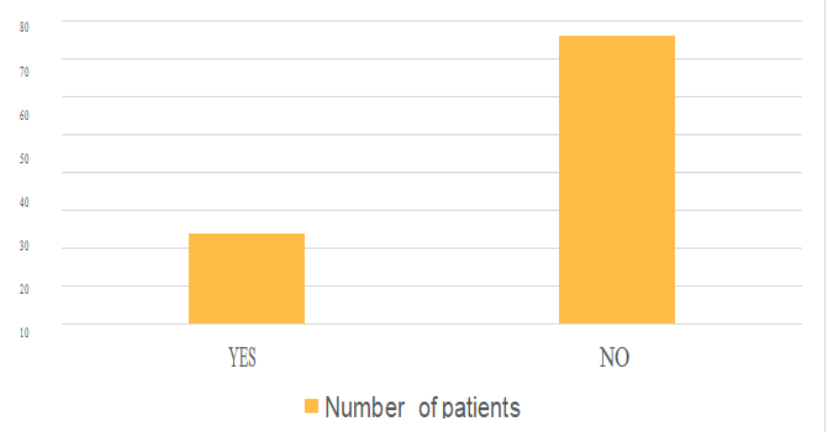

Fig 8:- Percentage of patients showing family history of breast cancer
Severity of side-effects in study population:

- Table 10: Representing the number of patients showing the severity of side-effects in the study population.

- Figure 9: Represents the frequency of severity of each side-effect.

\begin{tabular}{|c|c|c|c|}
\hline \multicolumn{3}{|c|}{ Table 10: Severity of side-effect. } \\
\hline & Mild & Moderate & Severe \\
\hline Nausea \& Vomiting & 34 & 48 & 62 \\
\hline Diarrhoea & 11 & 20 & 33 \\
\hline Insomnia & 9 & 17 & 38 \\
\hline Asthenia & 16 & 12 & 22 \\
\hline Pain & 6 & 27 & 11 \\
\hline Black-nails & 7 & 11 & 14 \\
\hline Anorexia & 7 & 7 & 13 \\
\hline Weakness & 2 & 10 & 5 \\
\hline
\end{tabular}

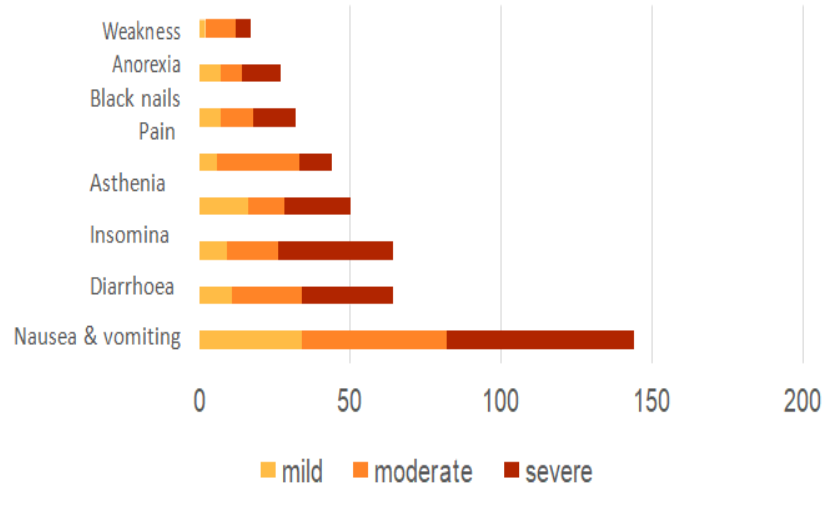

Fig 9:- Severity of Side-effects.

\section{CONCLUSION}

The frequent use of chemotherapy and our kind interest in the study of adverse drug reactions helped us to formulate the present topic. The study analysed common side-effects seen during chemotherapy of breast cancer in the hospital. Various parameters like body mass index (BMI), weight changes, menopause status, family history, hormone receptor status, tumor size, surgical data and reoccurrence status among study population were included. Analysis showed a gradual weight loss in patients after a few cycles of chemotherapy and mostly peri-menopause women were admitted with breast cancer. The study emphasized the need to focus on management of other sideeffects occurring like weakness, neutropenia, alopecia, 
gastrointestinal problems during chemotherapy along with management of nausea, vomiting and pain. The study highlighted the enthusiasm among the study population regarding diet and diet pattern to be followed during chemotherapy of breast cancer. There is a need for close monitoring over side-effects, muscle strength, weight changes, psychological health of the patient and maintaining a separate data sheet or detailed written form for this purpose to help overall patient care.

\section{REFERENCES}

[1]. Devesh Tewari, Pooja Rawat and Pawan Kumar Singh, Adverse drug reactions of anticancer drugs derived from natural sources, Food and Chemical Toxicology, 10.1016/j.fct.2018.11.041,(2018).

[2]. Zhang X, Tourgoer SS, Eliassen Ah, Hankinson SE. Postmenopausal plasmasexhormonelevelsandbreastcancerriskover20ye arsoffollow- up. Breast Cancer Res Treat. 137(3):88392, 2013.

[3]. Meagan Whisenant, Bob Wong, Sandra Mitchell, Susan Beck and Kath Mooney, Distinct Trajectories of Fatigue and Sleep Disturbance in Women Receiving Chemotherapy for Breast Cancer, Oncology Nursing Forum, 10.1188/17.ONF.739-750, 44, 6, (739750),(2017).

[4]. Mekhail TM, Markman M, Paclitaxel in chemotherapy, Exp Opin Pharmacother. 2002;3:75566.

[5]. Rowinsky Ek, Donehower RC, Paclitaxel (Taxol), N Engl Med. 1995; 332: 1004-14.

[6]. Foucher P, Camus P. Groupe d' Etude de la Pathologie Pulmonaire latrogene. The drug-induced respiratory disease; 2014.

[7]. Devesh Tewari, Pooja Rawat and Pawan Kumar Singh, Adverse drug reactions of anticancer drugs derived from natural sources, Food and Chemical Toxicology, 10.1016/j.fct.2018.11.041,(2018).

[8]. P. Cresta Morgado, M. Daud, M. Carballido, G. Mendez, S. Ideas, V. Lobbe, G. De Simone and A. Navigante, Relationship between skeletal muscle function, body composition, and weight loss in patients with advanced pancreatic and gastrointestinal cancers, Supportive care in Cancer, 10.1007/s00520018-4421-9, 27, 4, (1181-1186), 2018.

[9]. Eisuke kogure, Tsuyoshi Hara, Takaya Ishii and Masaharu maeda, Changes in fatigue and physical function with age for patients with gastrointestinal cancer in the peri-operative period: a comparison between older and young patients, Journal of Physical Therapy Science, 29,11,2004, 2017.

[10]. Chemotherapy-induced alopecia and effects on quality of life among women with breast cancer: a literature review. Lemieux, Julie 1,2,3,4,5*; Maunsell, Elizabeth 1,2,6; Provencher, Losie 1,2,7 [Review] PsychoOncology. 17(4): 317-328, April2008.

[11]. Shulamith Kreitler, Specific Cancer Diseases: The Psychological Perspective, Psycho-Oncology for the Clinician, 10. 1007/978-3-030- 06126-5_14, 247-266, 2019.
[12]. Sandra Otto, Rahmen bedingungen fur eine Erwerbstatigkeit: Zwischen Krebs, Job(undAlltag),ArbeitentrotzKrebserkrankung, 10.1007 1978-3-662-54883-7_6, (97-140),(2017).

[13]. World Health Organization. Global Cancer Rates Could Increase by $50 \%$ to 15 Million by 2020 .

[14]. World Health Organization. Breast Cancer Prevention and Control. 2016.

[15]. Tuncer M. Significance of cancer in Turkey, the burden of disease and cancer control policies. In: Cancer Control in Turkey. Ankara: Onur Press, Health Ministry Publication: 2008 pp5-9.

[16]. Shelburne N, Adhikari B, Brell J et al. Cancer treatment-related cardiotoxicity: current state of knowledge and future research priorities. J Natl Cancer Inst 2014;106 (9).Doi:10.1093/jnci/dju232.

[17]. Yeh ET and Bickford CL. Cardiovascular complications of cancer therapy: incidence, pathogenesis, diagnosis and management. J Am Coll Cardiol 2009; 53:2231-2247, doi: 10.1016/j.jacc.2009.02.050.

[18]. D. J. Park and H. P. Koeffler, " Therapy-related myelodysplastic syndromes," Seminars in Hematology, vol. 33, no. 3, pp. 256-273,1996.

[19]. W. Kern, T. Haferlach, S. Schinttger, W. Hiddemann and C. Schoch, "Prognosis in therapy-related acute myeloid leukaemia and impact of karyotype, "Journal of Clinical Oncology, vol.22,no.12,pp.2510-2511, 2004.

[20]. Dumontet C, Jordan M (2010) Microtubule-binding agents: a dynamic field of cancer therapeutics. Nat Rev Drug Discov 9(10):790-803.

[21]. Bahl A, Oudard S, Tombal B, Ozgurog M, LuHS, etal. (2013) Impact of cabazitaxel on 2-year survival and palliation of tumor-related pain in men with metastatic castration-resistant prostate cancer treated in the TROPIC trial. Ann Oncol 24:2402-2408.

[22]. Ahmann DL, Bisel HF, Hahn RG. A phase 2 evaluation of 1 ( 2 chloroethyl) 3 (4 methylcyclohexyl) 1 nitrosourea (NSC 95441) in. Cancer Research1974:34:27-30.

[23]. Z, Chen S, Engler SC, Lee HI, Atas E, von Maltzahn G, Bhatia SN, Hammond PT. Angew Chem Int Ed. 2019;49:7266.

[24]. Ottaiano A, di Palma A, Napolitano M, Pisano C, Pignata S, Tatangelo F, Botti G, Acquaviva AM, Castello G, Ascierto PA, laffaioli RV, Scala S. Cancer Immunol Immunother. 2005;54:781.

[25]. Catzavelos C, Bhattacharya N, Ung YC, Wilson JA, Roncari L, Sandhu C, Shaw P, Yeger H, MoravaProtzner L, Kapusta L, Franssen E, Pritchard KI, Slingerland Jm. Nat Med. 1997;3:277.

[26]. Baselga J, Norton L, Albanell J, Kim YM, Mendelsohn J. Cancer Res. 1998;58:2825.

[27]. Ahmann Dl, Schaid DJ, Bisel HF, Hahn RG, Edmonson JH, Ingle JN. The effect on survival of initial chemotherapy in advanced breast cancer: poly chemotherapy. Journal Clinical Oncology 1987;5:1928-32. 